\title{
Kegiatan Pelatihan Mengelola Event di Kelurahan Meruyung Depok
}

\author{
Firman Syah ${ }^{\varpi}$, Maswir \\ Program Studi MICE, Jurusan Administrasi Niaga, Politeknik Negeri Jakarta \\ Jalan Prof. DR. G.A. Siwabessy, Kampus Universitas Indonesia Depok 16425

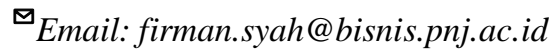

\begin{abstract}
The training in managing events for the community in Meruyung Urban Village in Depok aims to prepare educational tourism managers to maximize business opportunities. In the future, events held in Meruyung Urban Village can run well. At present, the potential of existing and existing tourist destinations is still considered stagnant.

The training priority of the packed event is pre event, event and post event. The three series of training can be carried out properly as a basis in preparing human resources who master the implementation of event activities.

Prior to the training, the community was first given an understanding of tourism destinations in accordance with Constitution No 10/2009 concerning Tourism, particularly Clause 14 on Tourism Services Business. The goal is to support the smooth running of educational tourism activities that have been carried out. It can also revive people's interest in managing tourist destinations in Meruyung Urban Village in Depok.

The result of the training was the community's interest in developing tirta tourism. Meruyung Urban Village has a pesanggrahan river that has begun to be managed and maximized. Because, two tourist destinations that exist today, namely the Dian Al-Mahri Mosque and 99 Village of Trees have been managed by the private sector.
\end{abstract}

Keywords: Tirta Tourism; MICE PNJ; Event; Community Dedication; and Meruyung Urban Village

\begin{abstract}
ABSTRAK
Kegiatan pelatihan mengelola event Kelurahan Meruyung Depok guna menyiapkan para pengelola pariwisata edukasi untuk lebih memaksimalkan peluang bisnis yang ada. Sehingga program unggulan event di Kelurahan Meruyung dapat dimaksimalkan dengan baik. Mengingat potensi destinasi wisata yang sudah berjalan saat ini masih dikategorikan stagnan.

Prioritas program kegiatan event dikemas mulai dari pre event, event, dan pasca event. Seluruh rangkaian kegiatan dalam event tersebut dilaksanakan secara baik dan detail sehingga mampu menyiapkan sumber daya manusia yang menguasai setiap step pelaksanaan event.

Selain itu, diawali dengan memberikan pemahaman seputar destinasi wisata yang ada di Kelurahan Meruyung sesuai dengan UU Nomor 10 Tahun 2009 tentang Kepariwisataan, khususnya Pasal 14 tentang Usaha Jasa Pariwisata. Hal ini guna menunjang kelancaran aktivitas wisata edukasi yang sudah dilaksanakan. Diharapkan bantuan material tersebut dapat membangkitkan kembali kepeminatan destinasi wisata yang ada di Kelurahan Meruyung Depok.

Hasil dari kegiatan ini, terlihat adanya ketertarikan dari masyarakat di Kelurahan Meruyung untuk mengembangkan wisata tirta. Dapat dilihat dengan adanya sungai pesanggrahan yang akan dimaksimalkan keberadaannya. Terlebih saat ini dua destinasi wisata yang ada yakni Masjid Dian Al-Mahri dan Kampung 99 Pepohonan sudah dikelola oleh swasta.
\end{abstract}

Kata Kunci: Wisata Tirta; MICE PNJ; Event; Pengabdian Masyarakat; dan Kelurahan Meruyung

\section{Pendahuluan}

Kegiatan pelatihan mengelola event di Kelurahan Meruyung Depok guna menyiapkan para pemangku kepentingan pariwisata yakni masyarakat lokal untuk lebih memaksimalkan peluang bisnis yang ada. Sehingga program unggulan event di dua destinasi wisata sekaligus dapat terlaksana dengan baik dan mengundang banyak wisatawan.
Prioritas program kegiatan event dikemas mulai dari pre event, event, dan pasca event. Seluruh rangkaian kegiatan dalam event tersebut dilaksanakan secara baik dan detail sehingga mampu menyiapkan sumber daya manusia yang menguasai setiap step pelaksanaan event.

Hingga saat ini, baru dua destinasi wisata yakni Masjid Dian Al-Mahri dan Kampung 99 Pepohonan yang menjadi 
andalan Kelurahan Meruyung. Namun, kedua destinasi wisata tersebut dikelola oleh masing-masing pelaku usaha dan minim melibatkan masyarakat lokal yang ada di Kelurahan Meruyung. Sementara untuk potensi yang ada dan bisa digarap oleh Kelurahan Meruyung Depok seperti sungai pesanggrahan maupun ekonomi kreatif terkait kerajinan daur ulang sampah yang dikelola ibu-ibu PKK.

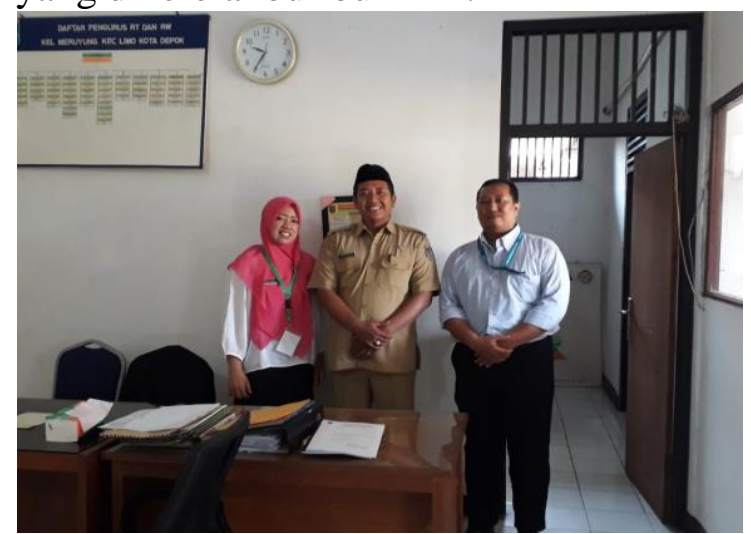

Gambar 1. Sosialisasi di Kelurahan Meruyung

Sehingga dalam mengembangkan desntinasi wisata tersebut, masyarakat lokal dapat melihat hambatan dan tantangan yang perlu dibenahi, antara lain:

a. Terobosan (inovasi) untuk membenahi destinasi wisata tirta.

b. Melihat kelebihan dan peluang yang ada namun tetap mengutamakan kearifan lokal.

c. Mengadakan event yang mampu mengundang wisatawan dalam jumlah besar.

d. Memperbaiki tampilan promosi termasuk melalui website sehingga lebih menarik.

e. Memberikan pemahaman kepada pengelola pentingnya terobosan pariwisata melalui bisnis yang lebih menguntungkan.

Atas dasar itulah kegiatan pengabdian kepada masyarakat kelompok dosen Program Studi MICE, Administrasi Niaga, Politeknik Negeri Jakarta dapat dilaksanakan. Hasil akhir dari kegiatan pengabdian masyarakat ini diharapkan masyarakat lokal memperoleh pengetahuan dan dapat membuat konsep destinasi wisata dan event yang baik.

Tujuan kegiatan pengabdian masyarakat ini adalah:

a. Memiliki pengetahuan terobosan (inovasi) untuk membenahi destinasi wisata tirta.

b. Dapat memetakan dan melihat kelebihan dan peluang destinasi wisata yang ada namun tetap mengutamakan kearifan lokal.

c. Mentrasfer pengetahuan dan pengalaman dalam mengelola event yang baik dalam wisata edukasi.

d. Pengelola dapat memahami model promosi yang baik dan dapat dimanfaatkan secara maksimal.

e. Membuat dan memiliki beberapa agenda event yang dapat dilaksanakan dalam waktu dekat atau beberapa tahun ke depan.

Adapun pengabdi terdiri dari dua dosen dari Prodi MICE, guna memberikan pembekalan kepada masyarakat lokal yang akan mengelola event dan disesuaikan keahlian kedua pengabdi tersebut. Untuk Firman Syah selaku ketua memberikan konsep umum pariwisata khususnya wisata MICE yang memiliki potensi bisnis dan Maswir memberikan konsep pengelolaan dan pemasaran event yang baik selain juga strategi mengundang sponsorship. Sehingga perlu memadukan ide kreatif dalam mengundang wisatawan, khususnya saat promosi melalui website.

\section{Metode Pengabdian}

Untuk melaksanakan kegiatan pengabdian kepada masyarakat kelompok dosen diuraikan ke dalam beberapa kegiatan baik yang sudah dilaksanakan maupun yang akan dilaksanakan selama tiga bulan sejak Juli 2019 sampai dengan Desember 2019, meliputi:

a. Sosialisasi yang dilaksanakan langsung di Kelurahan Meruyung (FGD) guna mencari permasalahan yang ada.

b. Setelah disetujui, langkah selanjutnya adalah penetapan isu sekaligus target 
siapa saja yang menjadi tamu undangan dalam pelatihan tersebut.

c. Pelaksanaan pelatihan yang berlangsung di Aula Kelurahan Meruyung sekaligus melakukan evaluasi dari kegiatan pelatihan tersebut.

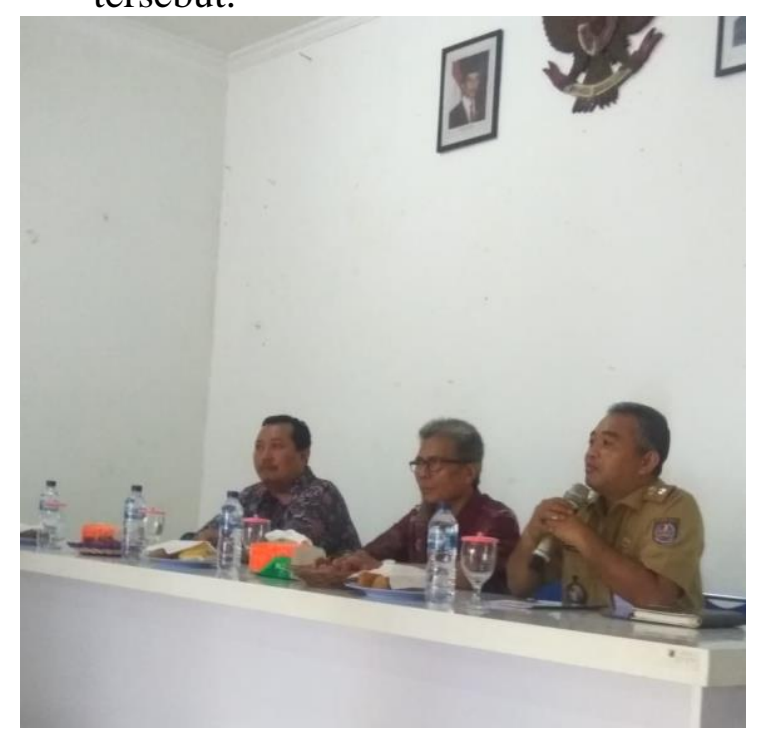

Gambar 2. Pembukaan Pelatihan Event

Dalam menyukseskan kegiatan pelatihan ini, juga melibatkan Kelurahan Meruyung sebagai mitra dengan tugas:

a. Melakukan kegiatan pertemuan guna menerima dan mempertimbangkan sebagai mitra kegiatan.

b. Melakukan koordinasi dengan seluruh stakeholder (RW dan RT juga tokoh masyarakat) untuk ditindaklanjuti kepentingan persetujuan kegiatan pengabdian kepada masyarakat.

c. Pembuatan administrasi guna mendukung kegiatan pelatihan, seperti surat menyurat dan undangan.

d. Menyiapkan sarana dan prasasarana yang dibutuhkan selama pelatihan, seperti ruangan dan sound system.

\section{Hasil dan Pembahasan}

Dalam membangun masyarakat lokal dapat dilakukan melalui kesadaran dari seluruh lapisan masyarakat. Secara bersama-sama mereka memiliki keinginan untuk membangun dan mengembangkan daerah sendiri sehingga melahirkan konsep pemberdayaan masyarakat sekaligus membuka lapangan pekerjaan. Mengingat saat ini, tidak sedikit masyarakat yang hanya mengandalkan jenis usaha dengan melamar sebagai pegawai di sebuah perusahaan. Ini sudah tertuang dalam UUD NKRI 1945 Pasal 33 (3) yang berbunyi bumi dan air dan kekayaan alam yang terkandung di dalamnya dikuasai oleh negara dan dipergunakan untuk sebesarbesar kemakmuran rakyat.

Artinya, beragam kebudayaan, tradisi, keindahan alam, kerajinan dan lain yang menjadi identitas suatu pulau merupakan sebagian kecil kekayaan yang dimiliki Indonesia. Bahkan, pada satu pulau dapat dijumpai perbedaan yang ada antara satu daerah dengan daerah lain. Inilah yang menjadikan Indonesia sebagai bangsa berdaulat. Sebagaimana semboyan negara, Bhinneka Tunggal Ika. Kelurahan/desa memiliki peluang untuk mengembangkan wilayah menjadi destinasi wisata. Diperlukan dasar-dasar kajian dalam sebagai data awal untuk studi kelayakan sebelum memutuskan konsep dan langkah menjadikan kelurahan/desa wisata selanjutnya (Syah, 2014).

Melalui konsep guna membangun ekonomi masyarakat lokal berbasis kewirausahaan sosial seperti di Kelurahan Meruyung Depok menjadi satu keharusan. Dimana terdapat proses guna meningkatkan kesejahteraan masyarakat melalui potensi sumber daya manusia, kondisi alam, potensi/keunikan budaya desa melalui pembinaan masyarakat desa demi kemajuan bersama. Dengan kalimat lain, SDM di daerah seperti di Kelurahan Meruyung dapat dimaksimalkan sehingga mampu membuka berbagai ragam pendapatan bagi masyarakat.

Tak heran daerah-daerah di Indonesia menggenjot beragam cara dan kegiatan untuk memaksimalkan Pendapatan Asli Daerah (PAD). Semakin besar PAD yang didapat, akan semakin menguatkan jatidiri sebagai daerah yang mandiri. Melalui PAD yang diperoleh tersebut, pembangunan di daerah akan semakin gencar dilaksanakan. Sehingga, dalam beberapa waktu ke depan 
daerah tersebut akan menjadi maju. Beragam kegiatan perekonomian yang menunjang daerah terlaksana dengan baik. Akhirnya, 'pintu' lapangan pekerjaan mulai terbuka lebar dan ikut membantu daerah dalam meningkatkan taraf hidup masyarakat sekitar (Syah, 2014).

Heri (2016) juga menegaskan seperti di Nglanggeran Yogyakarta, bahwa kegiatan wisata pedesaan pembangunan dilakukan oleh Kelompok Sadar Wisata (Pokdarwis) dan dianggap cukup baik. Indikator yang muncul adalah rata-rata peningkatan kunjungan wisatawan yang cukup besar dengan karakteristik wisatawan yang sangat beragam. Kesiapan masyarakat Lokal dalam hal aspek pendidikan, pengetahuan, keterlibatan masyarakat lokal dalam pengembangan menunjukkan bahwa mayoritas masyarakat telah cukup siap untuk menghadapi potensi dampak yang timbul.

Di samping juga, masyarakat dapat mencari sponsor dari perusahaan untuk mengembangkan daya tarik produk yang ada, misalnya program Corporate Social Responsibility (CSR). Melalui kegiatan CSR, perusahaan mengajak masyarakat untuk menyalurkan ide, aspirasi dan pendapat terkait apa yang menjadi harapan dan tujuan masing-masing pihak. Berkaitan dengan community development, CSR perusahaan dilakukan bersama komunitas (masyarakat) sekitar dengan kegiatan sejenis pengembangan masyarakat lokal agar mampu memberi manfaat dalam jangka waktu yang panjang bagi perusahaan dan masyarakat itu sendiri (Triyono, 2017).

Terlebih jika di satu desa tersebut memiliki banyak ragam kreativitas seperti daur ulang limbah sampah menjadi kerajinan dengan nilai jual tinggi. Pemberdayaan melalui ekonomi kreatif untuk meningkatkan kesejahteraan masyarakat seperti di Desa Sawo, UD Arjuna Stone melakukan tahap-tahap pemberdayaan masyarakat mulai dari penyadaran, pemberian kemampuan, dan peningkatan kemampuan masyarakat.
Dampak positif pemberdayaan masyarakat ini dapat membuka lapangan pekerjaan baru, menambah pendapatan masyarakat, menambah kualitas pendidikan dan keadaan sosial masyarakat (Fauzi, 2019).

Sebelum menjelaskan kendala yang ada, terlebih dulu dijabarkan langkahlangkah dalam melaksanakan kegiatan pengabdian kepada masyarakat. Dari langkah demi langkah tersebut dapat diketahui kendala yang muncul, dimulai:

\section{Persiapan}

Program pengabdian kepada masyarakat untuk menerapkan konsepkonsep pengelolaan event sehingga dapat meningkatkan pemahaman dan pengetahuan masyarakat lokal di Kelurahan Meruyung, Kecamatan Limo, Kota Depok dalam memperoleh pendapatan. Adapun kegiatan tersebut dimulai dari 30 Agustus 2019 sampai dengan 5 November 2019. Kegiatan ini terdiri dari tahap pencarian mitra, sesi sharing (FGD) dengan perwakilan kelurahan, tokoh masyarakat, tokoh agama, karang taruna, dan PKK, hingga evaluasi hasil kesepakatan bersama.

Beberapa kendala yang muncul saat kegiatan persiapan ini antara lain:

a. Pemilihan destinasi wisata yang memiliki potensi menarik untuk kegiatan pengabdian kepada masyarakat. Walau Kabupaten Bogor juga memiliki banyak destinasi wisata yang menarik, namun pilihan jatuh di Kelurahan Meruyung, Kota Depok. Alasannya masih satu kota dengan keberadaan Politeknik Negeri Jakarta. Kelurahan Meruyung sendiri menjadi salah satu destinasi yang memiliki potensi wisata dibandingkan dengan kelurahan yang lain di Kota Depok.

b. Waktu menjadi kendala juga terkait pemilihan destinasi. Mengingat saat itu, ada persiapan akreditasi Program Studi MICE dan masih kekurangan data untuk pengabdian masyarakat. Sehingga dibuatlah satu proposal dan kemudian mencoba untuk diajukan, walau saat itu posisi deadline 
pengumpulan proposal sisa satu hari. Mitra pun diperoleh setelah proposal dinyatakan dibiayai. Itu mengapa, saat proposal kali pertama diajukan belum ada mitra serta ada perubahan destinasi setelah dilakukan pencarian dan analisis dari semula pengajuan Kampung 99 Pepohonan pada akhirnya berubah ke Kelurahan Meruyung sebagai mitra kegiatan pengabdian kepada masyarakat.

c. Adanya keraguan sebelum memutuskan Kelurahan Meruyung, karena melihat dua destinasi wisata yang ada saat ini (Masjid Dian AlMahri dan Kampung 99 Pepohonan) dikelola oleh swasta. Adapun masyarakat lokal belum memiliki peluang untuk ikut campur. Namun, setelah dilakukan diskusi barulah diketahui jika ada potensi besar yang dimiliki oleh masyarakat lokal dan dapat dimaksimalkan keberadaannya.

d. Saat mengadakan FDG dengan pihak Kelurahan Meruyung awalnya juga sulit untuk menentukan/memilih kebutuhan program kegiatan pengabdian kepada masyarakat. Hal ini, lantaran Kelurahan Meruyung memiliki program kerja yang perlu disesuaikan dengan kebutuhan saat ini sebelum akhirnya diterima kegiatan pelatihan mengelola event karena karang taruna Kelurahan Meruyung sedang mengembangkan inovasi dan memanfaatkan peranan sungai pesanggrahan sebagai wisata tirta.

e. Konsolidasi menjadi kendala selanjutnya karena seringkali petugas Kelurahan Meruyung, yakni Kasi Inovasi (Ibu Rina) ada tugas kantor dan ketika akan ditemui sedang tidak di tempat. Sehingga sebagian besar koordinasi teknis untuk menyukseskan penyelenggaraan kegiatan pelatihan mengelola event dilakukan melalui komunikasi via online (whatsup) atau telepon.

Namun demikian, kelima poin tersebut bukan menjadi kendala yang besar. Karena adanya kerjasama yang baik dari pihak pelaksana dan pemerintahan di Kelurahan Meruyung dalam menyukseskan kegiatan pengadian masyarakat tersebut. Segala persiapan untuk kegiatan pengabdian kepada masyarakat berbasis kelompok dosen dari PNJ pun kemudian ditanggapi dan dengan cepat ditentukan waktu penyelenggaraan dengan membuat surat undangan kepada perwakilan tokoh masyarakat dan tokoh agama serta karang taruna dan PKK yang ada di Kelurahan Meruyung. Persiapan teknis ini juga melibatkan diskusi kecil dari pihak Kelurahan Meruyung yang awalnya mempertanyakan untuk apa kegiatan program pengabdian masyarakat diadakah di wilayah tersebut hingga muncul hal-hal teknis terkait kejelasan program pengabdian kepada masyarakat secara praktis untuk membantu masyarakat bukan hanya saat ini (pengabdian masyarakat).

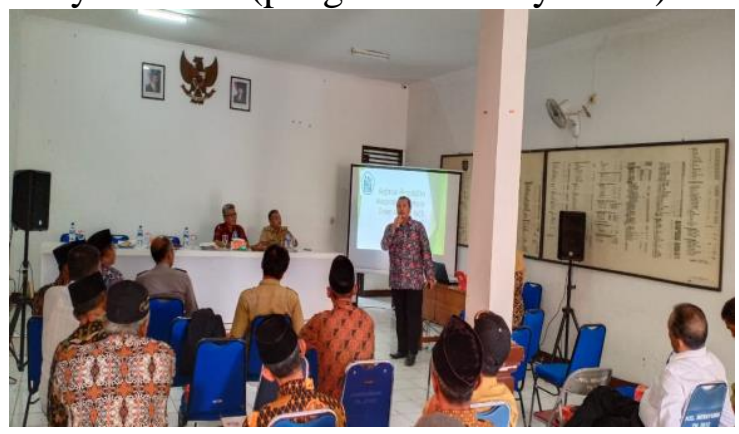

Gambar 3. Pembicara 1 Firman Syah

Kerangka pemecahan masalah yang dirancang dalam kegiatan pengabdian kepada masyarakat dalam bentuk pelaksanaan kegiatan pelatihan adalah:

a. Penjelasan konsep tentang pariwisata dan usaha jasa pariwisata yang legal sesuai dengan UU Nomor 10 Tahun 2009 tentang Kepariwisataan supaya memahami ragam usaha jasa pariwisata yang dapat dilaksanakan oleh masyarakat lokal.

b. Memberikan pemaparan pentingnya merancang dan melaksanakan event management guna memberikan motivasi dan masyarakat lokal dapat merancang kegiatan yang dapat dilaksanakan di Kelurahan Meruyung. 
c. Evaluasi hasil pelatihan yang dilakukan melalui umpan balik secara langsung atas kegiatan pelatihan yang sudah dilaksanakan.

\section{Pelaksanaan}

Pelaksanaan kegiatan pengabdian kepada masyarakat yang sudah disepakati bersama yakni Selasa 5 November 2019 menghadirkan seluruh perwakilan tokoh masyarakat, tokoh agama, karang taruna, dan PKK. Seluruh peserta yang hadir tersebut menakup 12 RW. Satu RW diundang 5 orang perwakilan yang terdiri dari perwakilan pengurus RW, perwakilan pengurus RT, perwakilan karang taruna, dan perwakilan PKK. Sehingga jika ditotal kehadiran peserta adalah 70 peserta dari 12 RW yang ada.

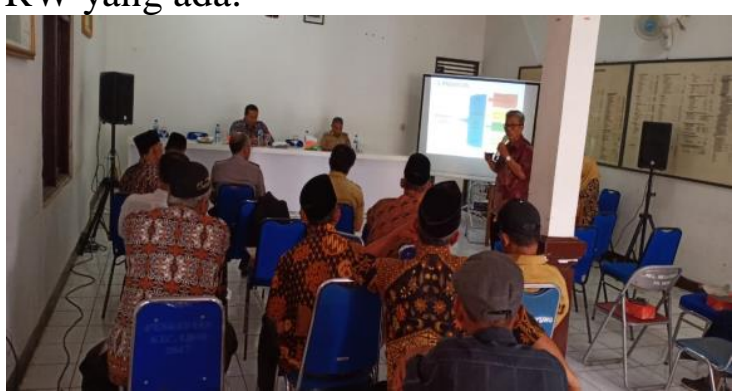

Gambar 4. Pembicara 2 Maswir

Kendala yang dihadapi dalam pelaksanaan kegiatan pengabdian kepada masyarakat berbasis kelompok dosen adalah:

a. Kehadiran peserta yang sudah ditentukan sejak awal tidak sesuai rencana. Berbagai alasan menjadi ketidakhadiran para peserta yang berasal dari masing-masing RW yang ada di Kelurahan Meruyung. Antara lain, waktu bekerja dan ada kegiatan yang lebih penting untuk dihadiri. Oleh karena itu, peserta yang datang dalam kegiatan pengabdian kepada masyarakat hanya 40 orang.

b. Akibat menunggu peserta yang dirasa belum komplit, maka acara yang semula dimulai 08.00 WIB sehingga diundur hingga peserta mulai memenuhi aula Kelurahan Meruyung. Hal ini jelas menjadikan rangkaian kegiatan pengabdian kepada masyarakat yang diadakan juga berubah. Namun, segala sesuatu yang sudah dijadualkan tetap dapat terlaksana dan tidak mengurangi sejumlah kegiatan. Hanya saja, beberapa materi diringkas dan diberikan tanpa mengurangi substansi.

c. Ada perwakilan RW yang ternyata kurang memahami kegiatan pengabdian kepada masyarakat berbasis kelompok dosen. Dimana perwakilan RW tersebut menganggap adanya fasilitas (bantuan material) yang didapat untuk memajukan pariwisata di Kelurahan Meruyung. Sejatinya, dalam kegiatan pengabdian kepada masyarakat tersebut tidak lain untuk memberikan gambaran dan solusi pemecahan masalah sehingga masyarakat dapat menemukan inovasi yang sesuai dengan kondisi lingkungan yang ada.

Walau demikian, pelaksanaan pengabdian kepada masyarakat tetap terlaksana dengan baik. Pada akhirnya seluruh lapisan masyarakat memahami jika bantuan yang bersumber dari pemerintahan butuh proses panjang dan untuk pengabdian kepada masyarakat bersifat pendidikan informal untuk mentransfer pengetahuan sehingga masyarakat lokal memiliki pedoman yang baik untuk mengelola suatu destinasi wisata di Kelurahan Meruyung khususnya di bidang event.

\section{Evaluasi}

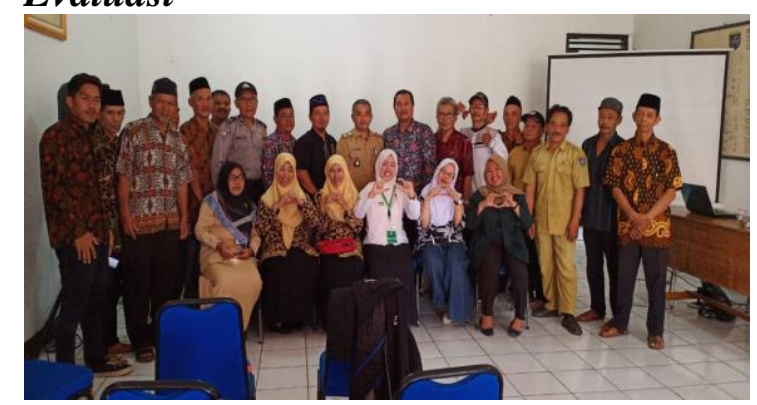

Gambar 5. Peserta Pelatihan Event

Tahap evaluasi ini tidak lain untuk melihat respon dari masyarakat lokal di Kelurahan Meruyung yang telah mengikuti kegiatan pelatihan mengelola event. Dari 
beberapa masukan dan respon yang diberikan oleh masyarakat lokal tersebut mayoritas mendukung kegiatan sealigus membutuhkan pendampingan sehingga pengembangan destinasi wisata khususnya wisata tirta yang dipadukan dengan MICE dapat terlaksana sepenuhnya.

Adapun kendala yang dihadapi saat melakukan evaluasi kegiatan adalah:

a. Pengumpulan data yang dilakukan terkendala kegiatan karena secara individu belum seluruhnya memberikan respon, sehingga dapat dikategorikan evaluasi hanya datang dari beberapa pihak. Maka, setelah kegiatan dilakukan wawancara langsung dengan pihak-pihak yang dirasa memiliki kompetensi baik dari pihak kelurahan, tokoh masyarakat, tokoh agama, karang taruna, maupun PKK. Hasilnya selain memiliki potensi wisata tirta, Kelurahan Meruyung juga memiliki potensi daur ulang sampah untuk kerajinan yang dapat dijual.

b. Kurangnya pemahaman masyarakat lokal terhadap pentingnya destinasi wisata dalam mendatangkan pendapatan bagi lingkungan, terlebih jika dipadukan dengan MICE yang lebih menekankan unsur bisnis. Padahal, ketika diterapkan sesuai dengan aturan yang telah diberikan pemerintah maka seluruh potensi yang ada di destinasi dapat memiliki keunggulan di bidang MICE. Kegiatan pengabdian kepada masyarakat dengan memberikan materi pengelolaan event bisa menjadi pengetahuan baru masyarakat sehingga banyak peluang dalam menjalankan bisnis.

c. Selama kegiatan pengabdian kepada masyarakat ini, terdapat kelemahan yang perlu diperbaiki dari destinasi wisata yang akan menjadi andalan Kelurahan Meruyung. Kesempatan dalam mengembangkan destinasi wisata harus dikemas pula dengan mengedepankan MICE atau merancang event-event dalam satu tahun untuk mendukung dalam mengundang wisatawan. Karena suatu event juga mampu menarik para pengunjung untuk hadir ke suatu tempat. Nantinya, jika diperlukan dan ada kesempatan untuk melakukan pendampingan dalam mengelola ecent dapat dilakukan secara bersama-sama.

\section{Kesimpulan}

Kegiatan pelatihan mengelola event di Kelurahan Meruyung Depok guna menyiapkan para pemangku kepentingan pariwisata yakni masyarakat lokal untuk lebih memaksimalkan peluang bisnis yang ada. Prioritas program kegiatan event dikemas mulai dari pre event, event, dan pasca event dan dilaksanakan secara detail. Dimulai dari persiapan yaitu sosialisasi, FGD, dan menyiapkan sarana prasarana. Selanjutnya pelaksanaan dilakukan dengan pembekalan materi tentang pariwisata dan mengelola event pada Selasa 5 November 2019. Terakhir adalah evaluasi guna melihat respon dari masyarakat yang mengikuti pelatihan di Kelurahan Meruyung.

\section{Ucapan Terima Kasih}

Kami pengabdi yang berasal dari kelompok dosen Program Studi MICE mengucapkan terima kasih kepada unsur pimpinan Politeknik Negeri Jakarta dan UP2M yang telah memberikan fasilitas kepada para dosen untuk melaksanakan kegiatan pengabdian masyarakat sebagai salah satu bentuk tridharma perguruan tinggi.

\section{Daftar Pustaka}

Fauzi, A. R. (2019). Pemberdayaan Masyarakat Melalui Ekonomi Kreatif Untuk Meningkatkan Kesejahteraan Masyarakat Perspektif Ekonomi Islam (Studi Kasus Kerajinan Batu Alam Wall Cladding di UD Arjuna Stone Desa Sawo Campurdarat Tulungagung). Skripsi. https://doi.org/10.1017/CBO9781107 
415324.004

Hery, H. (2016). Dampak Pengembangan Desa Wisata Nglanggeran Terhadap Ekonomi Masyarakat Lokal. Jurnal Pariwisata, $I I I(2), 64$.

Syah, F. (2014a). Destinasi Wisata Sebagai Aset Daerah. News.Detik.Com. https://news.detik.com/opini/2595172 /destinasi-wisata-sebagai-aset-daerah

Syah, F. (2014b). Membangun Konsep Kelurahan/Desa
News.Detik.Com.

https://news.detik.com/opini/d2586516/membangun-konsepkelurahandesa-wisata

Triyono, A. (n.d.). Pemberdayaan Masyarakat Melalui Community Development Program Posdaya (Pos Pemberdayaan Keluarga) PT. Holcim Indonesia Tbk Pabrik Cilacap.

Undang-Undang Dasar Negara Kesatuan Republik Indonesia Tahun 1945. 